\title{
Prestasi Belajar Siswa Madrasah Aliyah Negeri (MAN) X Sleman Yogyakarta Ditinjau Dari Dimensi Religiusitas
}

\author{
Sutipyo R. dan Amrih Latifah \\ Universitas Ahmad Dahlan (UAD) Yogyakarta \\ sutipyo@pai.uad.ac.id,
}

\begin{abstract}
Religiosity is an important element because religiosity as a "drive" in person's life. Religiosity, also expected to affect a person's success in learning. This study took place in a Madrasah Aliyah Negeri X Sleman, Yogyakarta. The method used quantitative approach to research subjects students of class XI with a total of 118 students with a sample of 84 people. The results showed a positive relationship with the Islamic Religiosity student achievement Madrasah Aliyah Negeri X SlemanYogyakarta, but the relationship is very low with indicated Pearson correlation value of 0.094 . After the regression test, the result shown that Islamic religiosity can not be used as a predictor to rise and fall on the students' learning achievement of the MAN.
\end{abstract}

Keywords: Religiosity Islami, predictors, Learning Achievement.

\begin{abstract}
Religiusitas adalah unsur penting, karena religiusitas sebagai drive dalam kehidupan seseorang. Religiusitas, diperkirakan juga mempengaruhi keberhasilan seseorang dalam belajar. Penelitian ini mengambil setting di sebuah Madrasah Aliyah Negeri X Sleman Yogyakarta. Metode penelitian yang digunakan adalah metode survei dengan pendekatan kuantitatif dengan subyek penelitian siswa kelas XI dengan jumlah total siswa 118 orang dengan sampel 84 orang.

Hasil penelitian ini menunjukkan ada hubungan positif Religiusitas Islami dengan prestasi belajar siswa Madrasah Aliyah Negeri X Sleman Yogyakarta, namun hubungan tersebut sangat rendah dengan ditunjukkan nilai korelasi Pearson sebesar 0,094. Setelah dilakukan uji regresi, ternyata Religiusitas Islami tidak dapat dijadikan prediktor akan naik turunnya prestasi belajar pada siswa MAN tersebut.
\end{abstract}

Kata kunci : Religiusitas Islami, prediktor, Prestasi Belajar. 


\section{A. Pendahuluan}

Religiusitas merupakan suatu dimensi psikologis yang sangat berpengaruh dalam setiap aspek kehidupan manusia. Kehidupan manusia yang tanpa religiusitas akan menjadi lemah dan tidak berdaya, karena kehidupan tanpa religiusitas akan berjalan tidak mempunyai arah yang jelas. Religiusitas menjadi drive dalam kehidupan seseorang, dan hal ini tentu juga berlaku pada seorang pelajar.

Semakin berkembangnya teknologi dalam kehidupan manusia ternyata mempunyai dampak yang signifikan dengan kekuatan religiusitas pada seseorang. Religiusitas (keberagamaan) mulai termarginalkan sehingga menjadi hal yang asing. Saat ini manusia merasa sangat tergantung dengan teknologi, sehingga seolah-olah tidak dapat hidup tanpa sentuhan teknologi. Teknologi saat ini menjadi tuhan baru bagi manusia yang memberikan "kekuatan".

Ditengah maraknya teknologi dan komunikasi yang telah diper-tuhan-kan oleh manusia, ternyata menyisakan banyak hal yang membuat hati menjadi miris. Capaian teknologi yang melonjak tajam ternyata tidak diiringi dengan kekuatan mental spiritual matang. Dekadensi moral terjadi di mana-mana bahkan diberitakan secara fulgar oleh media massa. Media massa juga telah kehilangan jati dirinya, sehingga memberitakan hal-hal yang tidak pantas diberitakan, kode etik jurnalistik diabaikan.

Persoalan merosotnya moral masyarakat (terutama generasi muda dan anak-anak) sudah menjadi hal yang sangat urgen 
untuk segera diatas secara kolektif. Ada sebagian masyarakat memikulkan beban ini kepada lembaga pendidikan (sekolah), bahkan sekolah menjadi kambing hitam sebagai salah satu penyebab dari kemerosotan moral. Sekolah dituntut untuk melakukan gerakan nyata terhadap perbaikan moral anak bangsa.

Salah satu gerakan nyata yang dilakukan pemerintah melalui kebijakan pendidikan adalah dengan memasukkannya pendidikan karakter dalam kurikulum (KTSP) sebagai hiden kurikulum yang harus diselipkan dalam setiap mata pelajaran. Perjalanan kebijakan ini ternyata belum memperlihatkan dampak yang signifikan. Kejahatan moral yang terjadi di masyarakat bahkan di sekolah masih terus mengalir. Pelakunya pun semakin bervariasi, mulai dari orang tua, remaja bahkan anak-anak.

Mensikapi kelumpuhan moral yang mencuat dititik nadir, pemerintah kembali menurunkan kebijakan agar di dunia pendidikan lebih menekankan aspek afektif spiritual dan aspek afektif sosial dalam aplikasi kurikulumnya. Kurikulum 2013 yang mulai diujicobakan sejak tahun 2013 dan diiplementasikan secara serempak pada tahun 2014 masih menyisakan pro dan kontra. Implementasi kurikulum 2013 ini sempat tarik ulur bahkan sampai dihentikan beberapa waktu.

Di dunia pendidikan Indonesia, Sekolah Menengah Atas menjadi tujuan utama orangtua melanjutkan sekolah anaknya setelah Sekolah Menengah Pertama. Hal ini terjadi sejak dahulu 
hingga akhir-akhir ini. Namun beberapa tahun terakhir ini ada hal yang menarik di dunia pendidikan, yaitu Madrasah (sekolah dibawah naungan Kementerian Agama), yang sebelumnya menjadi sekolah kelas "bawah" yang tidak dilirik oleh orangtua, kini mulai bergeliat bahkan madrasah-madrasah tertentu menjadi tujuan utama orangtua siswa lulusan sekolah menengah pertama untuk memasukkan anaknya.

Berkembangnya minat orangtua menyekolahkan anaknya ke madrasah menggugah penulis untuk meneliti lebih jauh. Madrasah yang saat ini mendapat kepercayaan orangtua untuk menyekolahkan anaknya seharusnya dapat "menyamakan" diri dengan sekolah umum dalam prestasi belajar siswanya. Lebihlebih madrasah mempunyai waktu belajar keagamaan yang lebih banyak, sehingga dapat meningkatkan motivasi belajar siswanya untuk meraih prestasi yang lebih baik. Untuk itulah, penelitian ini ingin menguak: Apakah pelajaran agama yang lebih banyak diberikan di madrasah dapat meningkatkan religiusitas siswa-siswinya? Dan apakah naik turunnya religiusitas dapat dijadikan prediksi pada naik dan turunnya prestasi siswa? Beberapa pertanyaan inilah yang menginspirasi penulis untuk meneliti di Madrasah Aliyah Negeri (MAN) X di Kabupaten Sleman Yogyakarta. Pemilihan MAN X ini didasarkan dari informasi yang menyatakan bahwa tahun-tahun sebelumnya MAN ini jumlah muridnya minimum, namun beberapa tahun terakhir jumlah muridnya meningkat tajam. 


\section{B. Teori Religisuitas Islami}

Setiap kali menelaah literatur tentang religiusitas, maka akan selalu muncul teori dari Glock dan Stark $^{1}$ yang menyatakan bahwa religiusitas itu terdiri dari lima dimensi yang meliputi: a) ideological (aspek akidah, menyangkut keyakinan dan hubungan manusia dengan Tuhan, malaikat, para Nabi, kitab, dan sebagainya), b) ritualistic (aspek ibadah, menyangkut frekuensi, intensitas pelaksanaan ibadah, yang telah ditetapkan, misalnya shalat, zakat, haji, dan puasa), c) consequential (aspek amal menyangkut tingkah laku dalam kehidupan bermasyarakat, misalnya menolong orang lain, membela orang lemah, bekerja secara professional dan sebagainya), d) experiential (aspek ihsan menyangkut pengalaman dan perasaan tentang kehadiran Tuhan, takut melanggar larangan, dan lain-lain), dan e) intellectual (aspek ilmu menyangkut pengetahuan seseorang tentang ajaran-ajaran agama).

Popularitas teori Glock dan Stark ternyata mulai surut dengan munculnya beberapa teori lain terutama teori religiusitas yang Islami. Di Indonesia, teori Glock dan Stark masih banyak

${ }^{1}$ Nashori, Fuad dan Mucharam, Rachmi Diana 2002. Mengembangkan Kreativitas dalam Perspektif Psikologi Islami. Yogyakarta: Menara Kudus Jogja. dan Sutipyo R. 2012. Peran Religiusitas Islami Terhadap Pemaafan Pada Remaja dengan Mediasi Kesejahteraan Subyektif (Subjective Well Being) Pada Siswa Madrasah Aliyah Negeri III Yogyakarta. Tesis. Yogyakarta: UAD. 
digunakan di dunia penelitian mulai dari tingkat skripsi, tesis bahkan disertasi. Akan tetapi, diluar teori Glock dan Stark mulai ditinggalkan dan muncul beberapa teori baru yang lebih Islami. Salah satu teori religiusitas yang muncul di Malaysia adalah HIRS96 yang di pelopori oleh S Mohamed Hatta (1996). Adapun aspek-aspek religiusitas menurut HIRS96 itu adalah sebagai berikut: a) Islamic Knowledge, yaitu pengetahuan tentang ke-Islam-an yang menyangkut tentang aqidah, akhlak dan ibadah. b) Islamic Practice, yaitu praktek atau pengamalan ibadah-ibadah mahdah maupun ibadah ghairu mahdah dalam seluruh kehidupan seseorang c) completion of Qur'an Reading, yaitu tingkat kerajinan dalam membaca kitab suci Al-Qur'an sehingga dapat menyelesaikan (mengkhatamkan) dalam beberapa waktu, dan d) Enjoining Good and Forbidding Wrong, yaitu kemampuan untuk beramar ma'ruf nahyi mungkar (mengajak kepada kebaikan dan melarang kepada kemungkaran).

Teori lain yang tidak kalah baiknya adalah yang dipaparkan oleh Steven Eric Kraus yang membagi dimensi religiusitas menjadi dua yaitu a) Islamic worldview (pandangan terhadap agama Islam yang lebih dikenal dengan akidah dan tauhid); dan b) religious personality (kepribadian agamis). Dalam disertasinya Kraus menguraikan dua dimensi religiusitas ini sebagai berikut:

1. Islamic worldview (Pandangan terhadap Islam yang lebih dikenal dengan akidah dan tauhid); aspek ini meliputi tiga 
sub aspek, yaitu a) creator and creation. Aspek ini dirancang untuk menilai hubungan antara manusia dan Tuhan. manusia sebagai bentuk tertinggi dari penciptaan dan Allah sebagai Pencipta segala. 'Pencipta dan ciptaan' mencerminkan unsur-unsur inti dari paradigma tauhid dan menilai pemahaman seseorang tentang ketergantungan pada Allah sebagai pemelihara dari semua kehidupan. Aspek ini sebagai indikator pemahaman seseorang tentang hubungan antara manusia dan Tuhan, menyiratkan kesadaran akan Tuhan. b) existence and transcendence. Aspek ini terdiri dari pernyataan tentang realitas tak terlihat berdasarkan pengetahuan inderawi. Ini termasuk elemen kunci dari enam tauhid, yaitu akhirat, hari kiamat, para malaikat, pahala dan hukuman; kelangsungan eksistensi setelah kematian, dan alam kehidupan setelah kehidupan di dunia. Aspek ini bertujuan untuk menilai pemahaman spiritual dari peristiwa dan realitas kesadaran spiritual dan nonragawi yang berbeda sesuai dengan perspektif Islam. Realitas seperti itu adalah prinsip utama dari suatu pandangan tauhid yang memandang realitas alam ghaib dan pahala serta hukuman sebagai sebuah kenyataan yang akan dialami setelah kematian. c) all encompassing religion. Aspek ini bertujuan untuk menilai pemahaman tentang Islam sebagai agama untuk semua, situasi waktu dan tempat.Untuk mengungkap ini, aspek ini item-item yang dibuat terkait dengan: fitrah (keadaan alami manusia); 
universalitas ajaran Islam; penerapan hukum Islam dan sunnah (jalan) Nabi, penerapan ajaran Islam di dunia modern, usia, dan lain-lain. Aspek ini mencakup sub-item yang berhubungan dengan penerapan ajaran Islam yang universal, yang bertindak sebagai indikator untuk pandangan yang konsisten dan pendekatan untuk hidup, konsisten dengan paradigma tauhid dan akidah Islam.

2. Religious personality (Kepribadian agamis). Aspek ini meliputi tiga sub aspek, yaitu a)Self (self-directed). Aspek ini bertujuan untuk menilai diri sendiri dalam perjuangannya untuk melandaskan Islam. Aspek internal diantaranya adalah kebajikan dan kejahatan seperti kerendahan hati, kesederhanaan, keberanian, kasih sayang, kejujuran, kecemburuan, iri, ketenangan, dan lain-lain. Aspek ini diungkap melalui pernyataan pada sikap, motivasi, emosi dan praktek-praktek atau perilaku. Dimensi ini merupakan hubungan seseorang dengan Allah berdasarkan kondisi diri seseorang. b) Social (interpersonal-interactive). Aspek ini bertujuan untuk menilai aspek sosial dan interpersonal yang berbasis agama atau dalam perspektif Islam. Ini mencakup kemampuan untuk memahami, bekerja dan berhubungan dengan tetangga, keluarga, seagama dan lain-lain. Aspek ini juga mengukur sejauh mana seseorang merespon motivasi, suasana hati, dan perasaan orang lain. Secara khusus, aspek ini meliputi mereka yang membangun 
interpersonal yang konsisten dengan kepribadian agama Islam seperti yang didefinisikan oleh Al-Qur'an, Sunnah. Aspek ini merupakan hubungan seseorang dengan Allah berdasarkan perilaku seseorang terhadap orang lain dan seluruh ciptaan. c) ritual (formal worship). Aspek ini bertujuan untuk menilai perjuangan pribadi yang terkait dengan ibadah mahdah atau ritual Islam. Berbeda dengan dua dimensi sebelumnya, dimensi ritual mencerminkan hubungan langsung seseorang dengan Allah melalui tindakan ritual seperti shalat, puasa, membaca Al-Qur'an, amal dan lain-lain. Aspek ini juga mencakup ketaatan kepada disiplin Islam eksternal seperti pakaian dan penampilan seseorang, serta item khusus untuk aturan hukum Islam. Aspek ini bertujuan untuk menilai tingkat komitmen seseorang terhadap perjuangan berislam secara $\mathrm{kaffah}^{2}$.

Jika diamati secara mendalam pandangan Krauss tentang dimensi religiusitas yang diungkapkannya sejalan hadits Rasulullah ketika berdialog dengan Jibril: "Ketika kami sedang duduk bersama Rasulullah Saw., tiba-tiba seorang laki-laki yang pakaiannya amat putih dan rambutnya amat hitam datang

${ }^{2}$ Krauss, S.E. Hamzah, A.H. Swandi, T. Noah, S.M. Mastor, K.A. Juhari, R. Kasan, H. Mahmoud, A and Manap, J. (2005) The Moslem Religiosity -Personality Measurement Inventory (MRPI)'s Religiosity Measurement Model: Towards Filling The Gaps in The Religiosity Research on Muslims. Pertanika J. Soc. Sci. \& Hum. 13 (2): 131-145 dan Sutipyo R. 
menghampiri kami. Tidak ada tanda-tanda bekas bepergian padanya dan tidak ada seorang pun dari kami yang mengenalnya. Ia duduk di hadapan Nabi Saw. seraya menyandarkan (merapatkan) kedua lututnya pada kedua lutut beliau, lantas ia meletakkan kedua tapaknya pada kedua paha beliau. Kemudian lelaki itu berkata: "Ya Muhammad, ceritakanlah kepadaku tentang Islam!” Rasulullah saw. Menjawab: "Islam ialah hendaknya kamu bersaksi bahwa tiada tuhan selain Allah dan Muhammad adalah utusan Allah; mendirikan shalat; membayar zakat; berpuasa di bulan Ramadhan; dan menunaikan haji ke Bantullah (Ka'bah), apabila kamu mampu." Ia berkata: "Kamu benar." Lantas tercenganglah kami terhadap sikapnya itu, sebab ia bertanya sekaligus membenarkannya. Lalu lelaki itu berkata: “Ceritakanlah kepadaku tentang iman." Beliau menjawab: "Hendaknya kamu beriman kepada Allah; malaikat-malaikatNya; kitab-kitab-Nya; Rasul-rasul-Nya; hari akhir; dan qadar baik dan buruk-Nya." Laki-laki itu berkata: "Kamu benar," kemudian ia berkata: "Ceritakanlah kepadaku tentang ihsan." Beliau menjawab: "Hendaklah kamu menyembah Allah seakanakan kamu melihatnya, apabila kamu tidak dapat melihatnya sesungguhnya Dia melihatmu." Lelaki itu berkata (lagi): "Ceritakanlah kepadaku tentang hari kiamat." Beliau menjawab: "Orang yang ditanya tidak lebih mengetahui dari pada yang bertanya." Lalu lelaki itu berkata: "Kalau begitu, ceritakanlah kepadaku tentang tanda-tandanya saja." Beliau 
menjawab: "Apabila hamba wanita telah melahirkan tuannya, manakala engkau melihat orang-orang yang tanpa alas kaki dan telanjang lagi banyak tanggungannya dan hidup sebagai pengembala kambing mulai berlomba-lomba membangun bangunan bangunan yang tinggi." Kemudian lelaki itu pergi. Selang beberapa saat Nabi Saw. bersabda: "Hai Umar, tahukah kamu siapa orang yang bertanya tadi?" Umar menjawab: "Allah dan Rasul-Nya yang lebih tahu." Beliau berkata: "Sesungguhnya ia adalah malaikat Jibril, yang datang untuk mengajarkan agama kepadamu", 3

Dari paparan teori religiusitas di atas, pendapat Steven Erick Kraus yang penulis anggap paling komprehensif. Hal ini disebabkan karena dari proses penyusunan dimensi-dimensi religiusitas Kraus bendasarkan pada pandangan Islam tentang agama.

Al-Attas $^{4}$ mengatakan bahwa konsep religiusitas yang terlahirkan dari istilah din dalam Islam berbeda dengan konsep religiusitas Barat. Secara ringkas, istilah din mengandung empat makna, yaitu a) keberhutangan, b) kepatuhan, c) kekuasaan bijaksana, dan d) kecenderungan alami atau tendensi. Keempat makna ini saling terkait menjadi satu makna yang menunjuk kepada iman, kepercayaan-kepercayaan dan praktek-praktek

3 HR. Muslim, dalam Rajab, Ibnu. 2006. Panduan Ilmu dan Hikmah, Syarah Lengkap Al-Arba'in An-Nawawi. Jakarta: Darul Falah.

${ }^{4}$ Sutipyo.... 
ajaran yang dianut oleh seorang muslim dalam kehidupannya sehari-hari.

Teori religiusitas Islami yang senada juga diuangkapkan oleh Mudjib ${ }^{5}$ yang menyatakan ada tiga prinsip dalam kepribadian manusia dalam pemeliharaan fitrah nafsani-nya yaitu: a) prinsip iman yang membentuk kepribadian muslim, b) prinsip Islam yang membentuk kepribadian mukmin, dan c) prinsip ihsan yang membentuk kepribadian muhsin. Prinsip kepribadian mukmin, yaitu kepribadian yang percaya sepenuh hati terhadap adanya Allah, malaikat, kitabullah (terutama AlQur'an), Rasul-rasul (terutama Nabi Muhammad SAW), hari akhir, dan baik buruknya takdir.

Dari beberapa teori yang telah diungkapkan di atas, menunjukkan betapa pentingnya reuligitas dalam kehidupan seseorang. Religiusitas mewarnai kehidupan seseorang dalam setiap langkah hidupnya. Tesis ini telah dibuktikan oleh beberapa penelitian diantaranya oleh Nashori dan Mucharam yang menghasilkan bahwa religiusitas mempengaruhi kreativitas seorang siswa. Penelitian Nanat juga menyimpulkan bahwa tingkat religiusitas memngaruhi etos kerja seseorang. Penelitian penulis tahun 2012 juga membuktikan bahwa religiusitas mempengaruhi secara langsung dan signifikan

${ }^{5}$ Mujib, Abdul. 1999. Fitrah dan Kepribadian Islam, Sebuah Pendekatan Psikologis. Jakarta: Darul Falah 
terhadap kebahagiaan seorang siswa dan mempengaruhi secara tidak langsung terhadap pemafaan siswa.

\section{Kerangka Berpikir dan Pengajuan Hipotesis}

Adanya beberapa hasil penelitian yang menyatakan bahwa religiusitas sangat bermakna dalam mendukung keberhasilan hidup seseorang, menjadi suatu fenomena yang menarik untuk dikaji lebih jauh. Sebagaimana yang dikatakan oleh Darajat ${ }^{6}$ bahwa religiusitas pada diri seseorang akan terpancar dalam kehidupan orang tersebut. Seorang yang religiusitasnya tinggi, akan mengalami kehidupan yang nyaman dan tenteram sehingga, mereka dapat menjalankan rutinitas kehidupannya dengan baik. Adapun manfaat religiusitas pada diri seseorang dalam kehidupannya diantaranya adalah:

a. Memberi bimbingan dalam hidup.

Pengendali utama kehidupan manusia adalah kepribadiannya yang mencakup segala unsur pengalaman, pendidikan dan keyakinan yang ditanamkan sejak kecil. Apabila dalam pertumbuhan seseorang terbentuk suatu kepribadian kepribadian yang harmonis, dimana segala unsur pokoknya terdiri dari pengalaman yang menentramkan hati, maka dalam menghadapi dorongandorongan, baik yang bersifat fisik maupun bersifat rohani

6 Daradjat, Zakiyah. 1982. Peranan Agama dalam Kesehatan Mental. Jakarta: Gunung Agung. Daradjat, Zakiyah. 1982. Peranan Agama dalam Kesehatan Mental. Jakarta: Gunung Agung. 
dan sosial, ia akan selalu wajar, tenang, tidak menyusahkan atau melanggar hukum.

b. Menolong dalam menghadapi kesukaran

Kesukaran yang banyak dialami manusia adalah kekecewaan. Apabila rasa kecewa sering terjadi pada diri seseorang dalam kehidupannya, maka orang tersebut akan tercebut pada perasaan rendah diri, pesimis, dan apatis dalam kehidupannya. Ketika mengalami kenyataan yang demikian, seseorang kadang mencari-cari kambing hitam dengan menyalahkan orang lain dan lain sebagainya.

Lain halnya dengan orang yang mempunyai religiusitas dan menjalanan syariat agamanya dengan baik. Baik orang yang mempunyai ketangguhan agama akan menganggap segala sesuatu yang dihadapi harus diterima dengan lapang dada. Dia merasa bahwa kesukaran dalam hidup tersebut merupakan cobaan bagi dirinya, dan dia masih mempunyai harapan bahwa dibalik kesukaran akan ada kemudahan.

c. Menenteramkan hati

Kegelisahan, kegundahan merupakan suatu hal yang terusmenerus akan menghampiri manusia. Keadaan yang berupa kegelisahan itu, kadang-kadang memuncak sampai pada titik kulminasi yang membuat seseorang seperti setengah mati. Dalam kegelisahan dan kepanikan itulah, religiusitas berfungsi sebagai pelita penerang yang menentramkan hati. Ketika pada titik kulminasi kegelisahan, seseorang biasanya diliputi oleh rasa putus asa yang sangat dalam. Dalam 
keadaan yang demikian inilah, agama hadir sebagai penyejuk hati yang sedang gundah gulana. Kepanikan, kekalutan dan kegundahan itu akan merengguk siapa saja, dan tidak terkecuali anak dan remaja.

Sementara itu, proses belajar belajar membutuhkan ketenangan dan ketenteraman hati, karena selama seseorang belajar akan mengalami kesukaran dan perjuangan yang tiada henti. Oleh karena itu, semua pelajar diperkirakan sangat membutuhkan religiusitas dalam keberhasilan pendidikannya. Dengan kerangka berpikir demikian, maka seluruh rangkaian persoalan yang diajukan dalam persoalan dihipotesiskan sebagai berikut: Pelajaran pendidikan agama yang lebih banyak diberikan di madrasah dapat meningkatkan religiusitas siswasiswinya. Dan Naik turunnya religiusitas seseorang siswa dapat dijadikan prediksi pada naik dan turunnya prestasi siswa tersebut.

\section{Metode Penelitian}

Pedekatan yang digunakan dalam penelitian ini adalah metode survei dengan pendekatan kuantitatif. Populasi penelitian ini adalah siswa-siswi kelas XI sejumlah 118 orang di MAN X, terdiri dari kelas XI IPA-1 sebanyak 19 orang, kelas XI IPA-2 sebanyak 18 orang, kelas XI IPS-1 sebanyak 31 orang, kelas XI IPS-2 sebanyak 31 orang, dan kelas XI Agama sebanyak 19 orang. Sedangkan penelitian ini menggunakan metode sampel dengan teknik Cluster random sampling. 
Penggunaan teknik ini, karena kelas XI sebagai populasi penelitian terdiri dari beberapa kelas, yaitu kelas XI IPA-1, kelas XI IPA-2, kelas XI IPS-1, Kelas XI IPS-2 dan Kelas XI Agama.

Penggunaan teknik Cluster random sampling, membawa konsekwensi bahwa setiap kelas mempunyai peluang yang sama untuk dijadikan sampel. Penentuan jumlah sampel pada penelitian ini menggunakan Nomogram Herry King ${ }^{7}$ dengan tingkat kesalahan 5\% adalah 84 orang. Kelas yang terpilih menjadi sampling pada penelitian adalah kelas XI IPA-1, kelas XI IPA-2, kelas XI IPS-1, dan Kelas XI Agama. Sedangkan Kelas XI IPS-2 tidak terpilih sebagai sampling, dijadikan sebagai responden untuk uji coba skala/angket.

Data religiusitas diambil dengan menggunakan angket yang dikembangkan dan diadaptasi dari teori Steven Eric Kraus, sedangkan data prestasi menggunakan dokumentasi sekolah yang berupa catatan raport.

Analisis data penelitian ini digunakan digunakan teknik statistik diskriptif untuk mengkatagorikan religiusitas dan prestasi siswa. Sedangkan untuk mengetahui adanya hubungan dan saling dapat memprediksi naik turunnya religiusitas dan prestasi belajar digunakan teknik analisis regresi sederhana ${ }^{8}$

7 Sugiyono. 2009. Metode Penelitian Pendidikan, Pendekatan Kuantitatif, Kualitatif dan R\&D. Bandung: Alfa Beta.

${ }^{8}$ Purwanto. 2011. Statistika Untuk Penelitian. Yogyakarta: Pustaka Pelajar 


\section{E. Analisis Hasil Penelitian}

Untuk mendeskripsikan hasil data penelitian, maka dilakukan pengelompokan data agar data penelitian mempunyai makna. Pengelompokan Religiusitas Islami siswa dengan menggunakan rumus norma kategori berdasar model distribusi normal yang berpatokan pada skor total, rerata hipotetik dan standar deviasi hipotetik. ${ }^{9}$ Berdasarkan rumus tersebut, diskripsi Religiusitas Islami siswa MAN X, sebagai berikut:

Kategorisasi skor Religiusitas Islami

\begin{tabular}{|c|c|c|c|c|}
\hline Variabel & Skor & Jml & $\begin{array}{c}\text { Persentas } \\
\text { e }\end{array}$ & Kategori \\
\hline \multirow{6}{*}{ 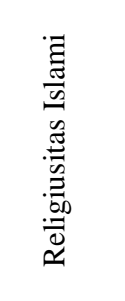 } & $X \leq 140,25$ & 1 & $1,1 \%$ & Sangat Rendah \\
\hline & $140,25<\mathrm{X} \leq 153,75$ & 4 & $4,6 \%$ & Rendah \\
\hline & $153,75<\mathrm{X} \leq 167,25$ & 25 & $29 \%$ & Sedang \\
\hline & $167,25<X \leq 180,75$ & 41 & $47,7 \%$ & Tinggi \\
\hline & $180,75<X$ & 15 & $17,6 \%$ & Sangat Tinggi \\
\hline & Total & 86 & $100 \%$ & \\
\hline
\end{tabular}

Berdasarkan tabel 2 dapat dilihat bahwa kondisi religiusitas siswa MAN X mayoritas berada pada posisi yang tinggi. Hal ini mendukung hipotesis bahwa MAN yang mempunyai jam belajar keagamaan dapat mendukung siswa-siswinya dapat meningkatkan religiusitasnya.

Sedangkan data prestasi belajar siswa yang diperoleh dari nilai raport dikelompokkan dengan menggunakan patokan nilai

${ }^{9}$ Azwar, Saifuddin. 2010. Validitas dan Reliabilitas Penelitian. Yogyakarta: Pustaka Pelajar. 
Kriteria Ketuntasan Minimal (KKM) yaitu nilai 75. Deskripsi peroleha nilai siswa MAN X, sebagai berikut:

Tabel 3

Kategorisasi prestasi belajar siswa

\begin{tabular}{ccccc}
\hline Variabel & Skor & Jml & Persentase & $\begin{array}{c}\text { Katego } \\
\text { ri }\end{array}$ \\
\hline & $\mathrm{X}<74,9$ & 40 & $46 \%$ & Rendah \\
\cline { 2 - 5 } & $75<\mathrm{X}<79,9$ & 34 & $40 \%$ & Cukup \\
\cline { 2 - 5 } & $80<\mathrm{X}$ & 12 & $14 \%$ & Tinggi \\
\cline { 2 - 4 } & Total & 86 & &
\end{tabular}

Dari tabel di atas dapat dilihat bahwa sebagian besar prestasi belajar siswa adalah rendah yaitu $46 \%$, sedangkan prestasi belajar yang tinggi sebesar 14\%. Besarnya prosentase atau jumlah siswa yang mempunyai prestasi rendah membuktikan bahwa madrasah belum berhasil meningkatkan prestasi siswa-siswinya sehingga prestasi madrasah masih rendah dibandingkan dengan sekolah umum.

Untuk menjawab hipotesis bahwa naik turunnya religiusitas dapat digunakan untuk memprediksi naik dan turunnya prestasi belajar dapat dilihat dari tabel rangkuman hasil analisis regresi sederhana sebagai berikut: 
Tabel 4

Rangkuman uji koefisien korelasi

\begin{tabular}{|c|c|c|c|c|c|c|c|c|}
\hline \multirow[b]{2}{*}{ Var } & \multicolumn{3}{|c|}{ Harga $r$ dan r2 } & \multicolumn{2}{|c|}{ Harga t } & \multirow[b]{2}{*}{ Koef } & \multirow[b]{2}{*}{ Konst } & \multirow[b]{2}{*}{ Ket } \\
\hline & $\mathrm{R}$ & $\begin{array}{l}\mathrm{r} \\
\text { square }\end{array}$ & $r_{\text {tabel }}$ & $t_{\text {hitung }}$ & $\mathrm{t}_{\text {tabel }}$ & & & \\
\hline $\mathrm{X}-\mathrm{Y}$ & 0.094 & 0.009 & 0,212 & 0,864 & 1,989 & 0,019 & 72,874 & $\begin{array}{l}\text { Ada } \\
\text { hubungan } \\
\text { yang } \\
\text { sangat } \\
\text { lemah }\end{array}$ \\
\hline
\end{tabular}

Tabel diatas menunjukkan bahwa nilai $\mathrm{R}=0,094$ dan koefisien Determinasi $\left(r_{\text {square }}\right)$ yaitu 0,009 . Hal ini menunjukkan pengertian bahwa prestasi belajar dipengaruhi oleh religiusitas Islami $0,9 \%$, sedangkan sisanya dipengaruhi oleh sebab-sebab yang lain. Sementara itu, $r_{\text {square }}$ berkisar antara angka -1 sampai 1, dengan catatan semakin kecil nilai $r_{\text {square }}$ berarti semakin lemah hubungan variabel. Dengan nilai $r_{\text {square }}$ sebesar 0,009 pada penelitian ini berarti: "Pengaruh tingkat Religiusitas Islami terhadap prestasi belajar siswa Madrasah Aliyah Negeri X Seleman Yogyakarta sangat lemah."

Nilai konstanta (a) sebesar 72,874 dan beta sebesar 0,094 serta nilai $t_{\text {hitung }}$ sebesar 0,064 pada tingkat signifikansi 0,390. Dengan demikian diperoleh persamaan hitungnya adalah = $72,874+0,094(\mathrm{X})$. Hal ini bermakna bahwa jika tidak ada Religiusitas Islami, maka Prestasi Belajar Siswa 72,874. Apabila ada Religiusitas Islami sebesar 1, maka Prestasi belajar juga akan naik sebesar 0,094. 
Dari tabel di atas dapat diketahui bahwa $t_{\text {hitung }}(0,864) \leq$ $t_{\text {tabel }}(1,989)$, artinya hipotesis minor 1 diterima dan hipotesis mayor serta hipotesis minor 2 ditolak, artinya: "Ada pengaruh yang tidak signifikan dari Religiusitas Islami terhadap Prestasi belajar siswa."

Adanya pengaruh yang tidak signifikan dari Religiusitas Islami terhadap Prestasi Belajar Siswa salah satuya dikarenakan bahwa pada kurikulum KTSP telah ditetapkan nilai KKM (Kriteria Ketuntasan Minimal. Ketentuan ini mengharuskan bahwa setiap siswa harus mencapai nilai ketuntasan yang telah ditetapkan oleh sekolah. Jika seorang siswa tidak mencapai nilai tuntas, maka guru dan siswa diwajibkan untuk melakukan remedial sampai akhirnya seorang siswa tersebut mencapai nilai KKM. Inilah salah satu sebab utama yang menghilangkan kemungkinan faktor-faktor yang menjadi peyebab naik turunnya Prestasi Belajar siswa tidak berperan maksimal sampai pada batas minimal nilai KKM.

Untuk pembuktian yang lebih konkrit apakah Religiusitas Islami dapat dijadikan prediktor atas prestasi belajar siswa, maka dapat dilihat pada hasil uji analisis varian (anova) sebagai berikut: 
Tabel 5

Hasil uji analisis varian

\begin{tabular}{|c|c|c|c|c|c|c|}
\hline \multicolumn{7}{|c|}{ ANOVA $^{b}$} \\
\hline \multirow[b]{2}{*}{ Model } & & \multirow{2}{*}{$\begin{array}{l}\text { Sum of } \\
\text { Squares }\end{array}$} & \multirow[b]{2}{*}{$\mathrm{df}$} & \multirow{2}{*}{$\begin{array}{l}\text { Mean } \\
\text { Square }\end{array}$} & \multirow[b]{2}{*}{$\mathrm{F}$} & \multirow[b]{2}{*}{ Sig. } \\
\hline & & & & & & \\
\hline \multirow[t]{3}{*}{1} & Regression & 5.250 & 1 & 5.250 & .746 & $.390^{a}$ \\
\hline & Residual & 591.012 & 84 & 7.036 & & \\
\hline & Total & 596.261 & 85 & & & \\
\hline
\end{tabular}

a. Predictors: (Constant), Religiusitas Islami

b. Dependent Variable: Prestasi Belajar

Pada tampilan hasil uji Anova di atas diketahui nilai $\mathrm{F}$ sebesar 0,746 dengan tingkat propabilitas sig. 0,390. Oleh karena nilai hasil propabilitas $(0,390)$ jauh lebih besar dari 0,05 , maka model regresi yaitu: "Religiusitas Islami tidak dapat digunakan untuk memprediksi naik turunnya Prestasi Belajar Siswa secara langsung."

Prestasi Belajar siswa tanpa Religiusitas Islami akan diperoleh sebesar 72,874 mengindikasikan besarnya faktorfaktor lain yang mempengaruhinya, seperti motivasi, minat, kedisiplinan, sikap dan faktor-faktor ekstrinsik yang lainnya yang dalam penelitian ini tidak diperhitungkan. Sebagaimana telah disebutkan Slameto ${ }^{10}$ bahwa prestasi belajar seseorang dipengaruhi oleh struktur kognitif dan struktur afektifnya.

${ }^{10}$ Slameto. 2013. Belajar dan Faktor-faktor yang Mempengaruhi. Jakarta: Rineka Cipta. 
Adapun struktur yang mempengaruhi kognitif peserta didik meliputi:

a. Persepsi yaitu proses yang menyangkut masuknya pesan atau informasi pada pembelajar.

b. Perhatian yaitu kegiatan seseorang yang berkaitan dengan pemilihan rangsangan yang datang pada lingkungannya.

c. Ingatan yaitu penarikan kembali informasi yang telah diperoleh sebelumnya.

d. Readiness (kesiapan) yaitu keseluruhan kondisi seseorang yang membuatnya siap untuk memberi respon jawaban dalam cara tertentu terhadap suatu situasi tertentu pula.

Sedangkan struktur yang mempengaruhi afektif peserta didik, antara lain:

a. Motivasi dan kebutuhan

b. Minat

c. Konsep diri

d. Sikap.

Kecilnya hubungan antara Religiusitas Islami terhadap Prestasi belajar pada hasil penelitian ini, tidak berarti bahwa Religiusitas Islami dapat dinafikan begitu saja dalam peningkatan prestasi belajar siswa. Adanya beberapa hal penting yang perlu diperhatikan berkaitan dengan perbedaan asumsi awal yang didasarkan pada landasan teori dan hasil penelitian sebagai berikut:

a. Penelitian ini tidak melakukan perhitungan pengaruh tidak langsung variabel prediktor. 
Hasil penelitian ini memang menunjukkan bahwa Religiusitas Islami mempunyai pengaruh langsung yang rendah, sebab pada penelitian ini tidak dapat diungkapkan pengaruh Religiusitas Islami terhadap Prestasi belajar yang tidak langsung. Dalam beberapa penelitian, terbukti Religiusitas Islami memberikan pengaruh tidak langsung yang cukup tinggi kepada suatu variabel. Misalnya penelitian yang dilakukan oleh Sutipyo ${ }^{11}$ membuktikan bahwa religiusitas memberikan pengaruh pada variabel tertentu melalui variabel intervening (variabel antara). Pada penelitian Sutipyo ini yang menghasilkan bahwa Religiusitas Islami memberikan pengaruh langsung yang sangat kecil terhadap pemaafan, akan tetapi memberikan pengaruh tidak langsung yang cukup besar terhadap pemaafan melalui variabel intervening yaitu variabel kesejahteraan subyektif .

Untuk membuktikan lebih jauh tentang hal ini mungkin dilakukan oleh para peneliti selanjutnya, yaitu menghubungkan religiusitas Islami dengan suatu variabel dengan menggunakan variabel intervening tertentu, misalnya minat, sikap, dan motivasi. Motivasi, minat, dan sikap, dapat dibentuk oleh unsur religiusitas. Senagaimana yang telah diungkapkan oleh Zakiyah Derajat bahwa keagamaan dapat menjadi penuntun hidup seseorang. Begitu pula dengan apa yang diungkapkan oleh Bagus

\footnotetext{
${ }^{11}$ Sutipyo R. 2012. Peran Religiusitas Islami ...
} 
Riyono, bahwa unsur keagamaan ketika menjadi pendorong (drive) dalam motivasi kekuatannya akan lebih bertahan lama dari pendorong yang lain.

b. Pengumpulan data variabel prestasi belajar penelitian ini pada menggunakan dokumentasi, bukan melakukan tes sendiri.

Penggunaan metode dokumentasi, memberi peluang data yang dikumpulkan kurang valid atau mempunyai validitas rendah. Lebih-lebih data ini adalah data rapot siswa yang bisanya nilai sudah melalui tahap katrol atau ujian ulang berkali-kali (remidial). Dalam kurikulum KTSP, diamanatkan seorang siswa harus dapat menguasai pelajar sesuai dengan KKM yang telah ditentukan. Ketentuan ini, membuat seorang guru berusaha sedemikian kuatnya agar anak didik dapat mencapai KKM yang telah ditentukan. Apabila seorang guru tidak dapat membimbing siswanya sampai pada KKN yang ditentukan maka guru tersebut akan mendapat predikat negatif (tidak berhasil). Hal inilah yang sangat dikhawatirkan dalam dunia pendidikan, dimana seorang guru lebih mementingkan nilai siswa yang mencapai KKM dari pada penguasaan materi/kecakapan yang sebenarnya. ${ }^{12}$

${ }^{12}$ Ramdhani, Neila. 2012. Menjadi Guru Inspiratif,Aplikasi Ilmu Psikologi Positif dalam Dunia Pendidikan. Jakarta: Titian Foundation. 
Hal ini sejalan dengan apa yang diungkapkan oleh Winkel (2012) ${ }^{13}$ bahwa hasil belajar tidak dapat disamakan dengan prestasi (hasil akhir). Prestasi belajar dapat haruslah nampak dalam seuatu kemampuan internal seseorang yang terwujud dalam seuatu bentuk perilaku.

c. Jumlah subyek penelitian terlalu minim. Suatu penelitian dengan analisis regresi disarankan bagi data yang tersedia cukup besar (diatas 100). Sementara pada penelitian ini jumlah populasi hanya 118 dan diambil sampel sebanyak 86 orang. Penggunaan sampel pada penelitian ini disebabkan karena kesulitan dalam melakukan uji instrumen. Jika instrumen diujicobakan di sekolah lain, dikhawatirkan diperoleh validitas dan reliabilitas rendah, karena karakter subyek penelitian berbeda (beda sekolah).

d. Kekhasan karakter rensponden. Menurut Noeng Muhadjir 14 perbedaan hasil penelitian dengan landasan teori yang dibangun oleh peneliti, diantaranya disebabkan oleh: 1) aspek-aspek variabel yang tidak (kurang) valid, 2) variabel terlalu besar sehingga perlu dilakukan pengambangan variabelitas, 3) Ada perbedaan subyek yang mencolok sehingga harus dilakukan pemecan subyek.

Keempat hal tersebut di atas yang sangat memungkinkan menjadi penyebab kecilnya hubungan antara Religiusitas

\footnotetext{
${ }^{13}$ Winkel W.S. 2012. Psikologi Pengajaran. Yogyakarta: Media Abadi.

${ }^{14}$ Sugiyono. 2009. Metode Penelitian Pendidikan, Pendekatan Kuantitatif, Kualitatif dan $R \& D$. Bandung: Alfa Beta.
} 
Islami dengan Prestasi belajar pada siswa Madrasah Aliyah Negeri X Sleman Yogyakarta.

\section{Kesimpulan}

Dari responden yang ada di lokasi penelitian MAN X Sleman Yogyakarta, ternyata MAN X belum bisa meningkatkan prestasi belajar siswanya ke peringkat yang baik dengan bukti bahwa 46\% siswa di MAN tersebut prestasinya tergolong rendah. Akan tetapi, hasil penelitian ini menunjukkan bahwa MAN X dapat mendongkrak dan menaikkan Religiusitas Islami dari siswa sisiwinya dengan prosentase $47,7 \%$ berada pada posisi Religiusitas Islami yang tinggi. Adapun hubungan antara Religiusitas Islami dengan prestasi belajar tergolong sangat lemah, bahkan analisis regresi sederhana diperoleh kesimpulan bahwa Religiusitas Islami tidak dapat dijadikan prediktor naik dan turunnya prestasi belajar.

Dengan hasil penelitian yang demikian ini, tidak berarti bahwa Religiusitas Islami tidak mempunyai peran terhadap peningkatan prestas belajar. Namun sangat dimungkinkan bahwa Religiusitas Islami masih mempunyai peran yang besar secara tidak langsung terhadap prestasi belajar. Oleh karena itu, peneliti menyarankan bagi peneliti Religiusitas Islami selanjutnya untuk menghubungkan variabel ini dengan beberapa variabel lain yang erat dengan penyebab lain dari prestasi belajar. 


\section{Daftar Pustaka}

Djamaluddin dan Suroso, Fuad Nasori. 1994Psikologi Islami Solusi Islam atas Problem-Problem Psikologi. Yogyakarta: Pustaka Pelajar.

Arikunto, Suharsimi. 1993. Prosedur Penelitian, SuatuPendekatan Praktek. Jakarta: Rineka Cipta.

Azwar, Saifuddin. 2010. Validitas dan Reliabilitas Penelitian. Yogyakarta: Pustaka Pelajar.

Daradjat, Zakiyah. 1982. Peranan Agama dalam Kesehatan Mental. Jakarta: Gunung Agung.

Daryanto. 2009. Panduan Proses Pembelajaran Kreatif dan Inovatif. Jakarta: AV Publisher.

Departeman Agama RI. 2002. Al-Qur'an dan Tafsirnya Jilid V. Jakarta: Departeman Agama RI.

Departemen Pendidikan dan Kebudayaan. 1993. Kamus Besar Bahasa Indonesia, cetakan IV. Jakarta: Balai Pustaka.

Dimiyati dan Mudjiono. 2013. Belajar dan Pembelajaran. Jakarta: Rineka Cipta.

Ghozali, Imam. 2011. Aplikasi Analisis Multivariate dengan Program IBMSPSS-19. Semarang: Badan Penerbit Universitas Diponegoro.

Idrus, Muhammad. 2012. Metode Penelitian Ilmu Sosial, Pendekatan Kualitatif dan Kuantitatif. (Jakarta: Erlangga

Krauss, S.E. Hamzah, A.H. Swandi, T. Noah, S.M. Mastor, K.A. Juhari, R. Kasan, H. Mahmoud, A and Manap, J. (2005) The Moslem Religiosity -Personality Measurement Inventory (MRPI)'s Religiosity Measurement Model: Towards Filling The Gaps in The 
Religiosity Research on Muslims. Pertanika J. Soc. Sci. \& Hum. 13 (2): 131-145

Mujib, Abdul. 1999. Fitrah dan Kepribadian Islam, Sebuah Pendekatan Psikologis. Jakarta: Darul Falah

Mulyasa, Enco. 2006. Kurikulum Tingkat Satuan Pendidikan. Bandung: Remaja Roda Karya

Nashori, Fuad dan Mucharam, Rachmi Diana 2002. Mengembangkan Kreativitas dalam Perspektif Psikologi Islami. Yogyakarta: Menara Kudus Jogja.

Natsir, Nanat Fatah. 1999. Etos Kerja Wirausahawan Muslim. Bandung: Gunung Djati Press.

Rajab, Ibnu. 2006. Panduan Ilmu dan Hikmah, Syarah Lengkap Al-Arba'in An-Nawawi. Jakarta: Darul Falah.

Ramdhani, Neila. 2012. Menjadi Guru Inspiratif,Aplikasi Ilmu Psikologi Positif dalam Dunia Pendidikan. Jakarta: Titian Foundation.

Riyono, Bagus. 2013. Motivasi dengan Perspektif Psikologi Islam. Yogyakarta: Quality Publishing.

Purwanto. 2011. Statistika Untuk Penelitian. Yogyakarta: Pustaka Pelajar.

Salleh, H.M. Hatta, S.M. Nor, M.I.M. Shamsuddin, K. Kassim, K. Ismail, R. Dan Moktar, N. (2000) Hatta Islamic Religiosity Scale 1996 (HIRS96) - A Reliability and Validity Study. Malaysian Journal of Psychiatry. Vol. 8, No. 1: 5-14.

Slameto. 2013. Belajar dan Faktor-faktor yang Mempengaruhi. Jakarta: Rineka Cipta.

Sugiyono. 2009. Metode Penelitian Pendidikan, Pendekatan Kuantitatif, Kualitatif dan R\&D. Bandung: Alfa Beta. 
Sutipyo R. 2012. Peran Religiusitas Islami Terhadap Pemaafan Pada Remaja dengan Mediasi Kesejahteraan Subyektif (Subjective Well Being) Pada Siswa Madrasah Aliyah Negeri III Yogyakarta. Tesis. Yogyakarta: UAD.

Sutipyo R. Pengaruh Religiusitas Islami terhadap Pemaafan pada Remaja. Jurnal Al-Misbah, STIT Muh. Wates. Volume I, No. 1, Tahun 2013, hlm. 61-89.

Suryabrata, Sumadi. 1995. Psikologi Pendidikan. Jakarta:Rajawali Press.

Winkel W.S. 2012. Psikologi Pengajaran. Yogyakarta: Media Abadi. 